\title{
Effect of apomorphine on growth hormone and prolactin secretion in schizophrenic patients, with or without oral dyskinesia, withdrawn from chronic neuroleptic therapy ${ }^{1}$
}

\author{
P. ETtigi, N. P. V. NAIR, S. LAL ${ }^{2}$, P. CERVANTES, AND H. GUYDA \\ From the Departments of Psychiatry, Douglas Hospital, Montreal General Hospital, \\ Queen Mary Veterans' Hospital, and Protein and Polypeptide Laboratory, Montreal, P.Q., Canada
}

SYNOPSIS Serum growth hormone $(\mathrm{GH})$ and prolactin (PRL) concentrations were measured after administration of the dopamine receptor agonist, apomorphine $\mathrm{HCl}(0.75 \mathrm{mg}$ subcutaneously), to 17 chronic schizophrenic patients, four of whom had an oral dyskinesia, who were withdrawn from chronic neuroleptic therapy for periods of two to 15 weeks, and in 21 control subjects (normal volunteers or physically healthy alcoholics not exposed to neuroleptics). Six of the schizophrenic patients, but none of the controls, had raised baseline levels of $\mathrm{GH}(>6 \mathrm{ng} / \mathrm{ml})$. After apomorphine all controls showed an increase in serum GH with a peak concentration of $9 \mathrm{ng} / \mathrm{ml}$ or more, whereas eight subjects withdrawn from neuroleptics showed an inadequate response (peak $<6 \mathrm{ng} / \mathrm{ml}$ ) and in two others an inadequate response was obtained on one of two trials. The peak GH concentration was significantly less after apomorphine in patients withdrawn from neuroleptics $(11.90 \pm 3.19$ $\mathrm{ng} / \mathrm{ml})$ compared with controls $(20.80 \pm 2.11 \mathrm{ng} / \mathrm{ml})(\mathrm{P}<0.05)$. Among patients withdrawn from neuroleptics, those with an oral dyskinesia had a significantly lower peak GH concentration (2.46士 $0.93 \mathrm{ng} / \mathrm{ml})$ after apomorphine compared with those without $(14.85 \pm 3.83 \mathrm{ng} / \mathrm{ml})(\mathrm{P}<0.05)$. There were no differences in serum PRL concentrations, before or after apomorphine administration, between patients withdrawn from neuroleptics and controls. In uncontrolled observations none of the four patients with an oral dyskinesia showed any worsening of the movement disorder after apomorphine. These data provide no evidence for supersensitivity of dopamine receptors in chronic schizophrenic patients withdrawn from chronic neuroleptic therapy.

Neuroleptic drugs block dopamine receptors (Horn, 1975) and this blockade is believed to render these chemically denervated receptors supersensitive (Rubovits and Klawans, 1972). Evidence for this derives from observations in animals demonstrating an enhanced behavioural response to the dopamine receptor agonist, apomorphine, after withdrawal of neuroleptic treatment (Tarsy and Baldessarini, 1973;

${ }^{1}$ This work was supported by grants from the Medical Research Council (Canada) (M.R.C. MT-4403 and MA-4838), and the Department of Veterans' Affairs (Canada). Additional support was received from Merck Frosst Laboratories, P.Q., Canada.

${ }_{2}^{2}$ Correspondence and reprint requests: S. Lal, Department of Psychiatry, Montreal General Hospital, Montreal, P.Q., Canada. (Accepted 20 April 1976.)
Gianutsos et al., 1974; VonVoightlander et al., 1975). Whether dopamine receptor function is enhanced after neuroleptic withdrawal in man is unclear, though such a mechanism has been implicated in the pathophysiology of tardive dyskinesia (Rubovits and Klawans, 1972).

Dopaminergic mechanisms modulate growth hormone (GH) and prolactin (PRL) secretion in man (Lal et al., 1972; Martin et al., 1974). Part of this evidence derives from observations that apomorphine stimulates GH secretion (Lal et al., $1972,1973,1975 \mathrm{a}, \mathrm{b})$ and inhibits that of PRL (Martin et al., 1974). Neuroleptics are believed to block hypothalamic dopamine receptors (Daughaday and Jacobs, 1972; Lal et al., 1973). 
In the present study we have evaluated hypothalamic dopamine receptor function in chronic schizophrenic patients with and without tardive dyskinesia who have been withdrawn from chronic treatment with neuroleptics by measuring GH and PRL response to apomorphine.

\section{METHODS}

All subjects were non-obese physically healthy men with no apparent endocrinopathy. All subjects had a normal serum alkaline phosphatase, serum glutamic oxaloacetic transaminase, total bilirubin, fasting blood sugar, blood urea nitrogen, urine analysis, and haemogram. Subjects 1-21 inclusive (Table 1) served as controls. Nine of these controls (subjects 1-9) were hospitalized alcoholics in a psychiatric ward. These hospitalized controls were tested with apomorphine two to six weeks after admission. Most had received benzodiazepine medication during their admission but all drugs were discontinued at least 48 hours before testing. The remaining control subjects were non-hospitalized volunteers without a psychiatric history and on no medication for at least two weeks before investigation. None of the controls had received a course of neuroleptic medication.

The experimental subjects 22-38 (Table 2) were mental hospital patients suffering from chronic schizophrenia. The diagnosis was based on the concurrence of two independent psychiatrists, and, in addition, fulfilled the research criteria for schizophrenia as described by Feighner et al. (1972). All but one of these patients had been on neuroleptic therapy (phenothiazines, thioxanthenes, or butyrophenones) for at least five years; all were in hospital continuously during the one year or more before investigation. The duration of neuroleptic therapy and duration of psychosis were one to 20 years $(9.8 \pm 1.3$, mean \pm standard error of the mean) and one to 37 years $(12.4 \pm 2.1)$, respectively.

TABLE 1

EFFECT OF APOMORPHINE ON SERUM GROWTH HORMONE (GH) AND PROLACTIN (PRL) CONCENTRATIONS IN NORMAL MEN*

\begin{tabular}{|c|c|c|c|c|c|c|c|c|c|c|c|c|c|}
\hline \multirow[b]{2}{*}{ Subject } & \multirow[b]{2}{*}{$\operatorname{Age}(y r)$} & \multicolumn{6}{|c|}{$\begin{array}{l}\text { GH }(\mathrm{ng} / \mathrm{ml}) \\
\text { Time }(\mathrm{min})\end{array}$} & \multicolumn{6}{|c|}{$\begin{array}{c}\text { PRL }(n g / m l) \\
\text { Time }(\mathrm{min})\end{array}$} \\
\hline & & -30 & 0 & 30 & 45 & 60 & Peak & -30 & 0 & 30 & 45 & 60 & Nadir \\
\hline 1 & 49 & $<1$ & $<1$ & 7.8 & 11.5 & 12 & 12 & - & 4.0 & 2.0 & 3.0 & 3.0 & 2.0 \\
\hline 2 & 48 & 1.4 & 1.4 & 20 & 15 & 6 & 20 & 7.0 & 5.0 & 6.0 & 5.0 & 5.0 & 5.0 \\
\hline 3 & 50 & 1.8 & $<1$ & 1 & 8.5 & 9 & 9 & 5.0 & 2.9 & 2.1 & 2.1 & 3.0 & 2.1 \\
\hline 4 & 51 & 3.7 & 1.2 & 14 & 14 & 13.5 & 14 & 8.4 & 6.0 & 4.3 & 3.5 & 4.2 & 3.5 \\
\hline 5 & 42 & 0.5 & 0.5 & 13.5 & 18 & 10 & 18 & 5.4 & 5.4 & 6.8 & 5.4 & 5.0 & 5.0 \\
\hline 6 & 39 & $<1$ & 1.5 & 14.5 & 24.5 & 21 & 24.5 & 1.0 & 1.0 & 1.0 & 1.0 & 8.0 & 1.0 \\
\hline 7 & 66 & $<1$ & $<1$ & 5.7 & 14 & 17.5 & 17.5 & 1.0 & 2.2 & 3.9 & 4.1 & 3.7 & 3.7 \\
\hline 8 & 45 & 1.5 & 3.3 & 19 & 18 & 11 & 19 & 3.4 & 2.8 & 1.7 & 3.0 & 5.0 & 1.7 \\
\hline 9 & 50 & $<1$ & 1.7 & 9 & 8 & 5.6 & 9 & 3.3 & 3.0 & 3.0 & 3.0 & 2.5 & 2.5 \\
\hline 10 & 36 & $<1$ & $<1$ & 20.5 & 36 & 42 & 42 & 13.0 & 10.5 & 12.5 & 12.5 & 9.5 & 9.5 \\
\hline 11 & 27 & $<1$ & $<1$ & 6.4 & 13.5 & 11.5 & 13.5 & 3.2 & 5.6 & 3.9 & 4.0 & 3.0 & 3.0 \\
\hline 12 & 26 & $<1$ & $<1$ & 9 & 14.5 & 11.5 & 14.5 & 4.3 & 3.1 & 1.4 & 2.7 & 2.2 & 1.4 \\
\hline 13 & 24 & $<1$ & 2 & 10.5 & 22.5 & 25 & 25 & 5.7 & 5.0 & 4.3 & 3.0 & 3.3 & 3.0 \\
\hline 14 & 30 & $<1$ & $<1$ & 10 & 27 & 27 & 27 & 2.7 & 2.3 & 3.2 & 1.4 & 2.0 & 1.4 \\
\hline 15 & 27 & $<1$ & 2 & 6 & 9.4 & 12 & 12 & 2.8 & 3.0 & 6.2 & 3.6 & 2.3 & 2.3 \\
\hline 16 & 31 & 1.1 & 1.1 & 14 & 15 & 13.5 & 15 & 8.6 & 5.7 & 5.1 & 8.4 & 5.8 & 5.1 \\
\hline 17 & 25 & 1.8 & 1.2 & 3.3 & 18 & 19 & 19 & 5.3 & 3.0 & 3.8 & 7.8 & 4.2 & 3.8 \\
\hline 18 & 21 & 1 & $<1$ & 13.5 & 33 & 24.5 & 33 & 6.8 & 6.2 & 7.0 & 9.0 & 5.7 & 5.7 \\
\hline 19 & 26 & 1.9 & 4.6 & 12.5 & 18 & 16.5 & 18 & 9.0 & 6.8 & 5.7 & 3.8 & 5.4 & 3.8 \\
\hline 20 & 26 & $<1$ & $<1$ & 4 & 15 & 40 & 40 & 4.8 & 5.0 & 3.3 & 3.1 & 6.2 & 3.1 \\
\hline 21 & 29 & & & 11 & 32 & 35 & 35 & 5.0 & 4.0 & 3.0 & 3.0 & 3.0 & 3.0 \\
\hline $1-21$ & 36.6 & 1.27 & 1.45 & 10.72 & 18.35 & 18.24 & 20.80 & 5.28 & 4.40 & 4.29 & 4.40 & 4.38 & 3.40 \\
\hline (Mean $\pm \mathbf{S E}$ & \pm & & \pm & \pm & \pm & \pm & \pm & \pm & \pm & \pm & \pm & \pm & \pm \\
\hline of mean) $\dagger$ & 2.7 & 0.14 & 0.20 & 1.17 & 1.74 & 2.27 & 2.11 & 0.65 & 0.45 & 0.56 & 0.61 & 0.42 & 0.41 \\
\hline Placebo & 28.3 & $<1$ & $<1$ & $<1$ & $<1$ & $<1$ & $<1$ & 6.00 & 5.18 & 3.40 & 3.96 & 4.31 & 3.11 \\
\hline $\begin{array}{c}\text { injection } \\
(n=6)\end{array}$ & \pm & & & & & & & \pm & $\begin{array}{l} \pm \\
0.81\end{array}$ & \pm & $\stackrel{ \pm}{1.22}$ & \pm & 0.77 \\
\hline
\end{tabular}

* Subjects received apomorphine $\mathrm{HCl}(0.75 \mathrm{mg}$ subcutaneously) at time ' 0 '. Peak and nadir are in reference to values after apomorphine administration.

$\dagger$ Values given as $<1$ have been given a numerical value of one for the purposes of statistical analysis.

$\ddagger$ PRL concentrations after placebo injection not significantly different from values after apomorphine. 


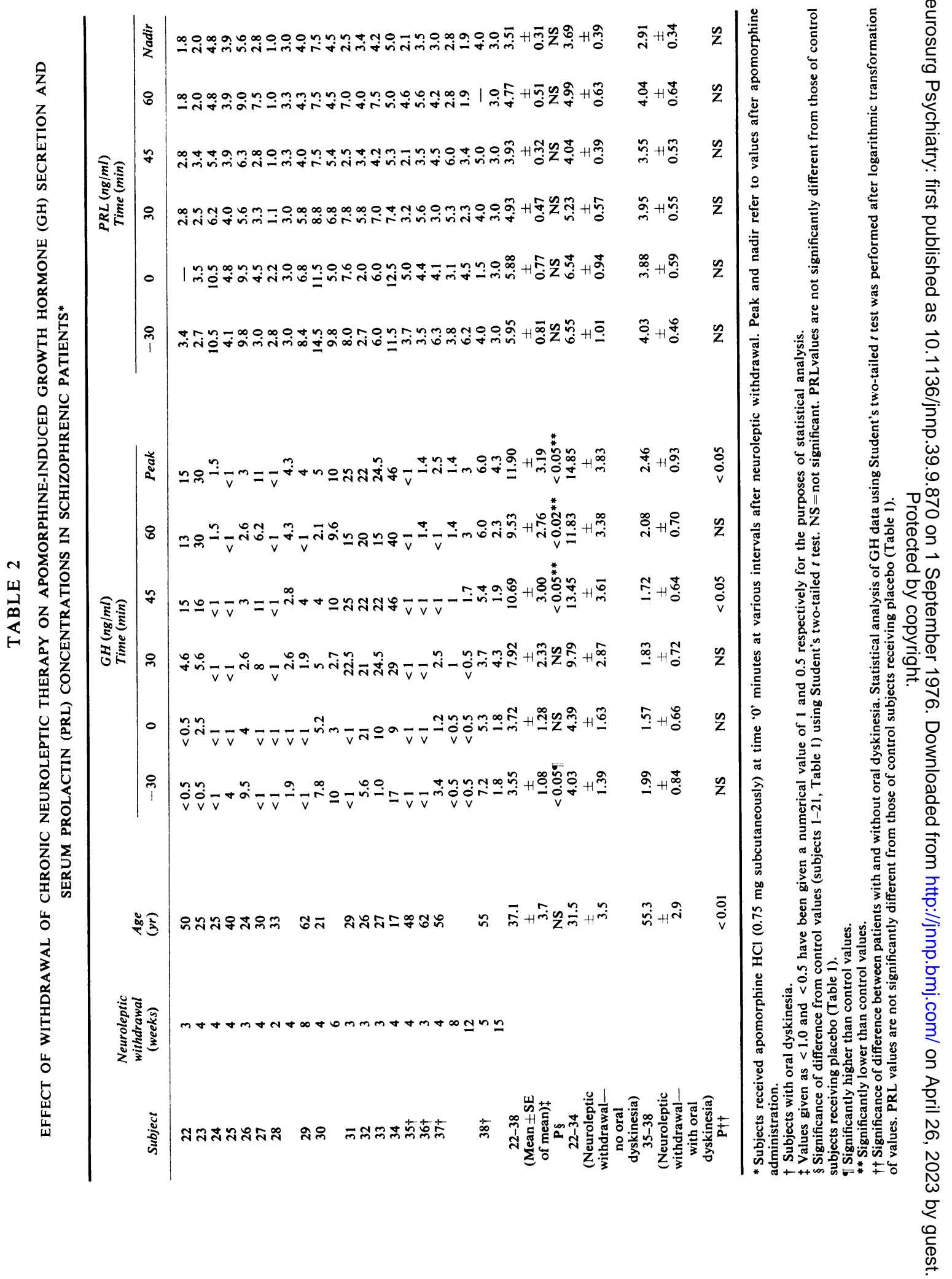


Subjects 35-38 inclusive had an oral dyskinesia (tardive dyskinesia) which persisted after neuroleptic withdrawal and was present when tested with apomorphine. Patient 38 had had a frontal lobotomy but otherwise none of the other experimental or control subjects had evidence of brain damage.

The average age of the controls and patients withdrawn from neuroleptics was $36.6 \pm 2.7$ years and $37.1 \pm 3.7$ years respectively, and the weight $69.5 \pm$ $1.8 \mathrm{~kg}$ and $67.6 \pm 2.7 \mathrm{~kg}$, respectively.

Medication was withdrawn from patients on neuroleptics for periods of two to 15 weeks before exposure to apomorphine. Four of these subjects were tested at more than one time interval after discontinuation of the drugs.

The apomorphine procedure was identical for both groups of subjects. In addition, six of the control subjects were also tested with placebo injection of apomorphine diluent alone. The apomorphine was made up in the pharmacy at the Montreal General Hospital in distilled water. Each $0.3 \mathrm{ml}$ contained $0.75 \mathrm{mg}$ apomorphine $\mathrm{HCl}, 0.375 \mathrm{mg}$ sodium metabisulphite (as an antioxidant), and $\mathbf{0 . 7 5}$ $\mathrm{mg}$ chlorbutanol (as a preservative). After an overnight fast, at 8.00 a.m. next morning a 19 gauge scalp vein needle was inserted into an arm vein and kept open with heparin-saline. At 9.00 and 9.30 a.m. baseline samples of blood were drawn and immediately after the 9.30 a.m. sample apomorphine $\mathrm{HCl}(0.75$ $\mathrm{mg}$ ) (or placebo) was injected subcutaneously and further samples of blood drawn at 30, 45 and 60 minutes after injection for determination of GH, PRL, and glucose. Samples for hormone determinations were immediately placed on ice until centrifuged and the serum then stored at $-20^{\circ} \mathrm{C}$ until assayed by radioimmunoassay (Friesen et al., 1970; Hwang et al., 1971). Glucose was measured by the ferricyanide reduction method using a Technicon Autoanalyser.

During the apomorphine test in the four patients with a tardive dyskinesia uncontrolled observations were made of the intensity and frequency of the oral dyskinetic movements which were rated as increased (slight, moderate, or marked), no change, or decreased (slight, moderate, or marked) at -30 , $-15,0,15,30,45$ and 60 minutes.

Baseline concentrations of $\mathrm{GH}$ of $6 \mathrm{ng} / \mathrm{ml}$ or more were considered to be raised and peak concentrations of less than $6 \mathrm{ng} / \mathrm{ml}$ were considered to be inadequate responses to apomorphine.

Data were analysed by the two-tailed $t$ test and the Pearson product moment correlation coefficient $(r)$ (Ferguson, 1966). In certain of the analyses where the subjects received apomorphine on more than one occasion, the mean GH peak concentration was used in the calculations.

\section{RESULTS}

The baseline serum $\mathrm{GH}$ levels in the control subjects varied from $1-4.6 \mathrm{ng} / \mathrm{ml}$ (Table 1). After apomorphine administration all 21 of these subjects showed a peak $\mathrm{GH}$ concentration of at least $9 \mathrm{ng} / \mathrm{ml}$ (range, 9-42 $\mathrm{ng} / \mathrm{ml}$; mean士 standard error of the mean, $20.80 \pm 2.11 \mathrm{ng} / \mathrm{ml}$ ). There was no increase in $\mathrm{GH}$ after placebo injection (Table 1).

The baseline serum GH concentration in patients withdrawn from neuroleptics was raised $(6 \mathrm{ng} / \mathrm{ml}$ or more) in six of the 17 patients at -30 minutes and/or ' 0 ' minutes. The mean value was significantly higher than in control subjects at -30 minutes $(\mathrm{P}<0.05)$ (Table 2$)$. After apomorphine administration, eight subjects withdrawn from neuroleptics showed an inadequate $\mathrm{GH}$ response (peak less than $6 \mathrm{ng} / \mathrm{ml}$ ); in two additional subjects an inadequate response was obtained on one of two trials. The range of peak values was $1-46 \mathrm{ng} / \mathrm{ml}$. The GH concentrations at 45 and 60 minutes as well as the mean of individual peaks (11.9土 $3.19 \mathrm{ng} / \mathrm{ml}$ ) in patients withdrawn from neuroleptics were significantly less than in controls $(\mathrm{P}<0.05-\mathrm{P}<0.02)$.

Four of the 17 patients withdrawn from neuroleptics had an oral dyskinesia (Table 2). Three of these patients had an inadequate GH response to apomorphine and the fourth had a peak value of $6.0 \mathrm{ng} / \mathrm{ml}$ on one occasion and $4.3 \mathrm{ng} / \mathrm{ml}$ on the second trial. The mean individual peak concentration in patients withdrawn from neuroleptics who were without an oral dyskinesia was $14.85 \pm 3.83 \mathrm{ng} / \mathrm{ml}$ and in those with an oral dyskinesia, $2.46 \pm 0.93 \mathrm{ng} / \mathrm{ml}$ $(\mathrm{P}<0.05)$.

There was no significant correlation between peak $\mathrm{GH}$ concentration and interval between drug withdrawal and exposure to apomorphine $(r=-0.24 ; \mathrm{df}=20 ; \mathrm{P}=\mathrm{NS})$. Subjects 37 and 38 who were withdrawn from neuroleptics for 12 and 15 weeks respectively developed an acute exacerbation of their psychosis within a day of the final testing with apomorphine. Early signs of deterioration in function in several of the other patients tested precluded longer periods of drug withdrawal.

The duration of neuroleptic therapy correlated highly with the duration of psychosis 
$(r=+0.85 ; \mathrm{df}=15 ; \mathrm{P}<0.01)$. There was a significant negative correlation between duration of neuroleptic therapy and peak GH concentration after apomorphine $(r=-0.48 ; \mathrm{df}=15$; $\mathrm{P}<0.05)$ but not between duration of illness and peak $\mathrm{GH}$ concentration $(r=-0.45 ; \mathrm{df}=15$; $\mathrm{P}=\mathrm{NS}$ ).

Baseline serum PRL levels were similar in control and experimental subjects. In the control patients prolactin concentrations after apomorphine were not significantly different from those after placebo injection (Table 1). There were no significant differences in PRL concentration between control and experimental subjects after apomorphine administration (Table 2).

Fasting blood glucose levels before and after apomorphine administration were similar in control subjects and in patients withdrawn from neuroleptics. Baseline values varied from 4.4 $5.8 \mathrm{mmol} / \mathrm{l}$ in controls and $4.7-5.8 \mathrm{mmol} / 1$ in experimental subjects and did not change significantly after apomorphine administration.

Apomorphine had no apparent effect on the intensity or frequency of oral dyskinetic movements.

All control and experimental subjects developed some yawning and drowsiness, usually within 10 minutes of the apomorphine injection. No other side effects were reported by the experimental subjects or in 11 of the control subjects. Ten control subjects experienced one or more of the following symptoms: lacrimation, mild abdominal cramps, diaphoresis, nasal congestion, dry mouth, headache, and transient nausea (five subjects).

\section{DISCUSSION}

Hypothalamic dopaminergic mechanisms modulate GH and PRL secretion in man (Lal et al., 1972; Martin et al., 1974). The dopamine receptor agonist, apomorphine (Sourkes and Lal, 1975) increases GH (Lal et al., 1972, 1973, 1975a,b) and decreases PRL secretion (Martin et al., 1974). Also, neuroleptics block hypothalamic dopamine receptors (Daughaday and Jacobs, 1972; Lal et al., 1973). It was therefore, expected that if prior treatment with neuroleptics increases the sensitivity of dopamine receptors, as occurs in animals (Tarsy and
Baldessarini, 1973; Gianutsos et al., 1974; Von Voightlander et al., 1975), then there might be an enhancement in these hormonal effects in patients withdrawn from chronic neuroleptic therapy after apomorphine administration, especially in those with an oral dyskinesia. Hypersensitivity of striatal dopamine receptors has been implicated in the pathophysiology of this latter condition and is believed to develop as a consequence of chronic treatment with neuroleptics (Rubovits and Klawans, 1972).

Our results show no evidence of an enhancement of $\mathrm{GH}$ response to apomorphine in chronic schizophrenics withdrawn from neuroleptics for two to 15 weeks compared with nonschizophrenic subjects not exposed to neuroleptics. Even in the patients with tardive dyskinesia there was no enhancement of $\mathrm{GH}$ response. In fact, our data point to a diminished GH response to apomorphine in patients withdrawn from neuroleptics and this diminished response is particularly evident in those patients with an oral dyskinesia. Three of the 17 patients withdrawn from neuroleptics had elevated $\mathrm{GH}$ levels at time 0 ; if data for these three subjects are excluded, the diminished $\mathrm{GH}$ response to apomorphine is even more pronounced in this group of subjects.

It is known that apomorphine $\mathrm{HCl}(0.75 \mathrm{mg})$ decreases serum PRL concentrations in patients with hyperprolactinaemia (Martin et al., 1974) but larger doses $(1.0-1.5 \mathrm{mg})$ are needed to decrease PRL levels in normal subjects (Lal et al., 1973). It was thought that if hypersensitivity of dopamine receptors develops in patients withdrawn from neuroleptic therapy then a decrease of PRL might be expected to occur with the dose of apomorphine used in the present investigation. There was, however, no difference in PRL concentrations in experimental and control subjects after apomorphine.

These data provide no evidence for hypersensitivity of dopamine receptors in chronic schizophrenics withdrawn from neuroleptics-at least those receptors modulating GH and PRL secretion. The failure of apomorphine to aggravate the dyskinetic movements in patients with an oral dyskinesia is not in keeping with the view that a hypersensitivity of striatal dopamine receptors subserves this movement disorder. It is possible, of course, that higher doses of apo- 
morphine are needed for such an effect. However, modification of extrapyramidal symptoms has been noted with $0.5 \mathrm{mg}$ apomorphine (Braham et al., 1970; Düby et al., 1972).

The reason for the diminished $\mathrm{GH}$ response in patients withdrawn from neuroleptics is unclear. Acute administration of neuroleptics antagonises apomorphine-induced GH secretion (Lal et al., 1973) so that it is possible that sufficient neuroleptic blockade of dopamine receptors persists beyond the period of two to 15 weeks of drug withdrawal. This explanation, however, is unlikely as serum PRL concentrations were not raised at these time periods. In this regard we have recently shown that the increase in serum PRL that occurs after acute neuroleptic administration persists in chronic schizophrenics maintained on chronic neuroleptic therapy for five years or more (De Rivera et al., 1976). It is possible, of course, that sufficient neuroleptic drug persists in the brain to affect dopamine receptors modulating $\mathrm{GH}$ but not those affecting PRL secretion.

All our patients withdrawn from neuroleptics were suffering from chronic schizophrenia so that it is possible that chronic schizophrenia itself affects neurohormonal responsiveness. Unfortunately, there is no information on the effect of apomorphine on $\mathrm{GH}$ response in untreated acute or chronic schizophrenics. Overactivity of dopaminergic systems in brain has been implicated in the aetiology of schizophrenia (Klawans et al., 1972; Angrist et al., 1973; Randrup and Munkvad, 1974). The findings in the present investigation indicate that in patients with chronic schizophrenia who are withdrawn from neuroleptics there is no increase in hypothalamic dopaminergic function.

In the present study the peak GH concentration was inversely correlated with the duration of neuroleptic therapy but not with duration of schizophrenia. Also, in schizophrenic patients with recognized neurological sequela of neuroleptic therapy-namely, tardive dyskinesia-the GH response was significantly less than in those without tardive dyskinesia. These data point to the diminished $\mathrm{GH}$ response as being a sequel of the effects of prior neuroleptic treatment rather than due to the psychosis itself, though how this might occur is unclear. It should be pointed out, however, that there were only four patients with tardive dyskinesia and the age of these patients was significantly higher than those schizophrenic patients without a dyskinesia. Increasing age has been reported to decrease the $\mathrm{GH}$ response to apomorphine (Maany et al., 1975), though this has not been found to be the case in our own unpublished results.

Hyperglycaemia (Ettigi et al., 1975) and obesity (Tolis et al., 1975), which may develop as a result of neuroleptic treatment (Korenyi and Lowenstein, 1968; Kalinowsky and Hippius, 1969), have been shown to decrease the $\mathrm{GH}$ response to apomorphine. In the present study blood glucose levels were normal in both experimental and control subjects; none of the subjects was obese. Both groups were well matched for age and body weight.

It is possible that prior exposure to chronic neuroleptic therapy alters the metabolism of apomorphine so that insufficient levels of the drug are maintained to stimulate $\mathrm{GH}$ secretion. Information on this in man is not available but, in the mouse, brain apomorphine levels are not affected by prior exposure to chronic neuroleptic therapy (VonVoightlander et al., 1975).

The mechanism underlying spontaneous bursts of $\mathrm{GH}$ is unknown (Martin, 1973). In the present study several of the patients withdrawn from neuroleptics had elevated GH levels before apomorphine administration. Whether this increased incidence of spontaneous bursts of $\mathrm{GH}$ secretion is related to prior neuroleptic treatment or to the chronic psychosis itself is unclear. Other workers have found normal baseline $\mathrm{GH}$ concentrations in chronic schizophrenics withdrawn from neuroleptics for seven to 10 days (Schimmelbusch et al., 1971; Vigneri et al., 1974) but in chronic schizophrenics untreated with drugs decreased concentrations have been reported (Schimmelbusch et al., 1971).

The authors acknowledge the technical assistance of J. Parodo.

\section{REFERENCES}

Angrist, B., Sathananthan, G., and Gershon, S. (1973). Behavioural effect of L-dopa in schizophrenic patients. Psychopharmacologia (Berlin), 31, 1-12.

Braham, J., Sarova-Pinhas, I., and Goldhammer, Y. (1970). Apomorphine in Parkinsonian tremor. British Medical Journal, 3, 768. 
De Rivera, J. L., Lal, S., Ettigi, P., Hontela, S., Muller, H. F., and Friesen, H. G. (1976). Effect of acute and chronic neuroleptic therapy on serum prolactin levels in men and women of different age groups. Clinical Endocrinology, 5, 273.

Daughaday, W. H., and Jacobs, L. S. (1972). Human prolactin. Ergebnisse der Physiologie, 67, 169-194.

Düby, S. E., Cotzias, G. C., Papavasiliou, P. S., and Lawrence, W. H. (1972). Injected apomorphine and orally administered levodopa in Parkinsonism. Archives of Neurology (Chic.), 27, 474-480.

Ettigi, P., Lal, S., Martin, J. B., and Friesen, H. G. (1975). Effect of sex, oral contraceptives, and glucose loading on apomorphine-induced growth hormone secretion. Journal of Clinical Endocrinology and Metabolism, 40, 1094-1098.

Feighner, J. P., Robins, E., Guze, S. B., Woodruff, R. A., Winokur, G., and Munoz, R. (1972). Diagnostic criteria for use in psychiatric research. Archives of General Psychiatry, 26, 57-63.

Ferguson, G. A. (1966). Statistical Analysis in Psychology and Education. 2nd edn. McGraw-Hill: New York.

Friesen, H. G., Guyda, H., and Hardy, J. (1970). Biosynthesis of human growth hormone and prolactin. Journal of Clinical Endocrinology and Metabolism, 31, 611-624.

Gianutsos, G., Drawbaugh, R. B., Hynes, M. D., and Lal, H. (1974). Behavioral evidence for dopaminergic supersensitivity after chronic haloperidol. Life .Sciences, 14, 887-898.

Horn, A. S. (1975). Structure-activity relations for neurotransmitter receptor agonists and antagonists. In Handbook of Psychopharmacology, volume 1, pp. 179-243, Edited by L. L. Iversen, S. D. Iversen, and S. H. Snyder. Plenum Press: New York.

Hwang, P., Guyda, H., and Friesen, H. (1971). A radioimmunoassay for human prolactin. Proceedings of the National Academy of Sciences, 68, 1902-1906.

Kalinowsky, L. B., and Hippius, H. (1969). Pharmacological, Convulsive and other Somatic Treatments in Psychiatry. Grune and Stratton: New York.

Klawans, H. L., Goetz C., and Westheimer, R. (1972). Pathophysiology of schizophrenia and the striatum. Diseases of the Nervous System, 33, 711-719.

Korenyi, C., and Lowenstein, B. (1968). Chlorpromazine induced diabetes. Diseases of the Nervous System, 29, 827-828.

Lal, S., de la Vega, C. E., Sourkes, T. L., and Friesen, H. G. (1972). Effect of apomorphine on human growth hormone secretion. Lancet, 2, 661.

Lal, S., de la Vega, C. E., Sourkes, T. L., and Friesen, H. G. (1973). Effect of apomorphine on growth hormone, prolactin, luteinizing hormone and folliclestimulating hormone levels in human serum. Journal of Clinical Endocrinology and Metabolism, 37, 719-724.
Lal, S., Martin, J. B., de la Vega, C. E., and Friesen, H. G. (1975a). Comparison of the effect of apomorphine and L-dopa on serum growth hormone levels in normal men. Clinical Endocrinology, 4, 277-285.

Lal, S., Tolis, G., Martin, J. B., Brown, G. M., and Guyda, H. (1975b). Effect of clonidine on growth hormone, prolactin, luteinizing hormone, folliclestimulating hormone, and thyroid stimulating hormone in the serum of normal men. Journal of Clinical Endocrinology and Metabolism, 41, 827-832.

Maany, I., Frazer, A., and Mendels, J. (1975). Apomorphine: effect on growth hormone. Journal of Clinical Endocrinology and Metabolism, 40, 162-163.

Martin, J. B. (1973). Neural regulation of growth hormone secretion. New England Journal of Medicine, 288, 1384-1393.

Martin, J. B., Lal, S., Tolis, G., and Friesen, H. G. (1974). Inhibition by apomorphine of prolactin s xcretion in patients with elevated serum prolactin. Journal of Clinical Endocrinology and Metabolism, 39, 180-182.

Randrup, A., and Munkvad, I. (1974). Pharmacology and physiology of stereotyped behaviour. Journal of Psychiatric Research, 11, 1-10.

Rubovits, R., and Klawans, H. L. (1972). Implications of amphetamine-induced stereotyped behaviour as a model for tardive dyskinesia. Archives of General Psychiatry, 27, 502-507.

Schimmelbusch, W. H., Mueller, P. S., and Sheps, J. (1971). The positive correlation between insulin resistance and duration of hospitalization in untreated schizophrenia. British Journal of Psychiatry, 118, 429-436.

Sourkes, T. L., and Lal, S. (1975). Apomorphine and its relation to dopamine in the nervous system. Advances in Neurochemistry, 1, 247-299.

Tarsy, D., and Baldessarini, R. J. (1973). Pharmacologically induced behavioural supersensitivity to apomorphine. Nature New Biology, 245, 262-263.

Tolis, G., Lal, S., Pinter, E. J., Martin, J. B., Guyda, H., and Solomon, S. (1975). Altered dopamine receptor sensitivity in obesity. Sixth International Congress of Pharmacology, July 20-25, 1975, Helsinki, Finland.

Vigneri, R., Pezzino, V., Squatrito, S., Calandra, A., and Maricchiolo, M. (1974). Sleep associated growth hormone $(\mathrm{GH})$ release in schizophrenia. Neuroendocrinology, 14, 356-361.

VonVoightlander, P. F., Losey, E. G., and Triezenberg, H. J. (1975). Increased sensitivity to dopaminergic agents after chronic neuroleptic treatment. Journal of Pharmacology and Experimental Therapeutics, 193, 88-94. 